\title{
Citizen participation and ecological diagnosis in two Mesoamerican Reef System Natural Protected Areas:Mexico and Honduras.
}

\author{
Adriana Isabel Gutiérrez-Castro,Alicia González-Solís and Daniel Torruco
}

Centro de Investigación y Estudios Avanzados del Instituto Politécnico Nacional, Unidad Mérida. Antigua Carretera a Progreso, Km 6. CORDEMEX. C.P. 97310. A.P. 73. Mérida, Yucatán, México. Tel: +52 (999) 9429400 ext. 2588

dantor6660@gmail.com

\begin{abstract}
Community participation in sustainable development projects is minimal or lacking in the natural protected areas (NPA) of Central America. Fifteen years after the Mesoamerican Reef System was implemented as an international conservation strategy, a study was done to determine local population interest in reef conservation in San Miguel de Cozumel, Mexico, and West End Village, Honduras. An evaluation was also done of coral health in nearby, heavily used reefs. Lack of community participation is linked to low levels of information, education and training, although $90 \%$ of interviewees agreed to participate in a contingent proposal involving financing of coral reef conservation activities. Participants exhibited a willingness-to-pay an average of $10 \%$ of income spent on basic food needs or the national minimum wage. Their willingness stemmed from the use value of the reefs as a tourist attraction and from their being a primary income source.Among non-use values, ensuring the well-being of their children (i.e. legacy value) was the most frequently stated followed by conserving reefs because they are a natural system (i.e. existence value). The reef coral health indicated some degree of reef deterioration compared to indicator values for the Mesoamerican Reef System. Greater community participation in NPA management and administration will require NPA authorities to develop tools for community interaction and to prove the effectiveness of their actions.
\end{abstract}

Key words: Mesoamerican reef system, natural protected areas; social participation, contingent value; ecological evaluation.

\section{Academic Discipline and subdisciplines}

Sociology and Ecology.

\section{Subject classification}

Library of congress classification

Type (Method/Approach)

Survey/Interview

\section{Council for Innovative Research}

Peer Review Research Publishing System

\section{Journal: Journal of Social Sciences Research}

Vol. 6, No. 1

Jssreditor.cir@gmail.com

www.jssronline.com 


\section{INTRODUCTION}

Coral reefs are one of the most beneficial ecosystems for human beings. They cover only $1 \%$ of the planet's surface but have $25 \%$ of known marine biodiversity and resources and environmental services represent 375000 million annually [1]. As of 2008, approximately 500 million people depended on them for food, coastal protection, building materials and tourism; 30 million of these users relied completely on reefs for subsistence [2]. The Mesoamerican reef system (MRS) is an immense reef system that provides subsistence for millions of users and substantial income for the nations with access to it. For example, in Honduras the reefs surrounding the Bay Islands attract tourism for scuba and free diving, producing substantial income for the national economy [3,4]. In Mexico, tourism in areas such as the Caribbean coast is so important that only the petroleum and manufacturing industries generate more income [5].

Nature tourism is growing within natural protected areas (NPAs) because these provide relatively well-preserved natural settings. Human communities within NPA areas of influence have developed alternatives to meet increasing tourist market demand. Governments in Central America have responded by dedicating resources to regional development strategies based on tourist and recreational use of biodiversity [6,7]. For diving tourism, the desire for risk and extreme recreational activities augments the attraction of the landscape (reefs, sea and coast). It is an increasingly popular activity, and the appeal of the overall diving experience has led approximately 1.5 million people a year to become certified worldwide [8].

Reefs' biological characteristics provide both economic and social benefits. Conservation efforts within the MRS are aimed at perpetuating ecological processes and protecting the system's biological diversity. This requires diagnoses of reef health in the area and an understanding of how use demands respond to prevailing reef health.

The conservation vision and mission of NPAs in Central America have not been built in conjunction with affected populations. As a result, coastal populations have resisted new reef fishing regulations, such as takelimits on protected species. This lack of coordination has had far-reaching, diverse implications on conservation and socio-economic wellbeing. Within this scenario of heavy and growing tourist use of MRS reefs, economic dependence of local populations on the reef system and a massive decline in coral populations, a study was done of two cases in the MRS region: San Miguel de Cozumel, Mexico and West End Village, Honduras. The analysis was done within the framework of more than ten years of international effort to include the human populations influenced by NPAs in their management. Using a hypothetical contingent scenario, an analysis was done of users' willingness-to-pay for coral reef conservation actions. This was treated as an indicator of potential interest and assigned value, and expressed in terms of average monthly payment (AMP).A coral structure biodiversity evaluation was done to quantify the ecological value of the reefs in the NPAs in question.

\section{MATERIALS AND METHODS Study area}

The MRS subregion encompasses the coral reef ecosystems stretching along the western Caribbean Basin, from Holbox Island, Mexico, to the Honduras/Nicaragua border. This system has no natural barriers to isolate it from the rest of the reefs in the greater Caribbean. Its coral formations are only apparently continuous and include formations such as bordering or coastal reefs, false atoll reefs and platform reefs [9] (Fig. 1).

The extent and limits of the MRS are conventional and political. They were proposed to allow development of joint conservation strategies among the countries involved. One conservation action taken by these governments was official declaration of marine protected areas [10]. The NPAs created within the MRS were intended to preserve the biological and cultural richness generated by coral reefs and the coastal zone. Cozumel Island (Quintana Roo, Mexico) and Roatan Island (Bay Islands, Honduras) are both located inside the MRS and include sizable NPAs. Both islands experience intense international tourism and recreational use, have rural communities highly dependent on reef systems, allow coastal residential growth and suffer environmental degradation. Cozumel has been the "home of tourism in the Mexican Caribbean" since the 1960s and is currently one of the largest cruise ship destinations in the world $[11,12,13]$. The main NPA in the area is Cozumel Reefs National Park, and San Miguel de Cozumel is the largest town on the island. In Honduras, the Bay Islands (Utila, Guanaja and Roatan) are the center of the country's fishing and tourism industries [3,4]. Roatan is almost surrounded by reefs and since the 1970s has been famous among divers for its reef walls. West End Village is probably the best known of the towns in the Bay Islands and is one of three towns within the West Bay, West End and Sandy Bay Marine Park. This town has the most attractive beaches on Roatan Island and the largest number of diving and tourist businesses [14,15].

\section{Methodology}

Social and ecological approaches were used in this study. Social data were collected by applying a semi-structured questionnaire with a multidisciplinary (biology, anthropology and economics) design in a direct interview following the contingent valuation method. The values assigned the reefs used by inhabitants of San Miguel de Cozumel and West End Village were identified and monetized in a contingent (theoretical) social participation scenario. A realistic proposal was used to determine the amount of money to contribute for a given purpose, and accompanied by a detailed proposal for funds payment and administration [16]. The scenario was based on a generalized decision by the inhabitants to cooperate (i.e. maximum willingness-to-pay-M-WTP) towards financing coral reef conservation actions. The problem was presented as increasing reef degradation and the funds would be collected and administered by a group of elected townspeople. Marine park administration and municipal governments would be excluded from participation. Each interviewee decided 
the amount and periodicity of his/her voluntary contribution. Non-use values (legacy, option and existence) were identified by asking about motives for cooperating; each interviewee decided what proportion of the total (100\%) to assign each motive. The three possible motives were benefits to children/grandchildren (legacy value); future personal benefit (option value); and because it forms part of nature (existence value). An open question was included to allow for other reasons or values. No information was provided to interviewees on the environmental services, biological or ecological aspects of coral reefs.

The ecological value of the reefs in the NPAs in question was quantified using an evaluation of coral structural biodiversity. Hard coral biological descriptors were determined with phototransects in each reef [17]. Biological sampling was done in two use zone types: intensive recreational diving use (ID); and non-intensive recreational diving use (NID). To facilitate comparison, contiguous zones were used with similar environmental characteristics and depths.

\section{Data analysis}

Using the socioeconomic and demographic characteristics of the samples, the analysis included results on the value assigned contingently to the reef; importance of the reef to the interviewee; interest in acting in favor of coral reefs; personal investment preferences (in favor of the environment or social well-being); and basic knowledge. Identification of true and protest zero values was useful in discussing results. A protest zero value was defined as all excessively large individual payment interest values. Extreme values were corrected, that is, they were excluded from monthly WTP (MWTP), mean, mode, standard deviation, correlation and linear regression calculations.

The M-WTP calculated for each town corresponded to the average value of individual M-WTP values. These are expressed in United States dollars at the exchange rate applicable during the sampling period (summer to winter 2008). In the statistical correlation, individual WTP data were grouped by demographic and socioeconomic variables: sex (male, female); age (18-25, 26-30, 31-10, 41-50 and 51-60 years); marital status (single, married/living with partner); economic activity (tourist services, public/other services); and education level (elementary school, junior high school and high school/vocational).

Biodiversity in each zone of the selected reefs was quantified by taking a series of images along a $20 \mathrm{~m}$ transect laid out with a polypropylene rope marked every meter. Images were taken from $80 \mathrm{~cm}$ distance using an Olympus Stylus digital submarine camera with a 10 megapixels definition (Cozumel),or a Canon Powershot 550 digital camera with housing and a 10 megapixels definition (Roatan). Each image was analyzed to quantify live coral coverage, expressed as $\mathrm{cm}^{2}$. Coral coverage results were used to generate a data matrix for each sampling site including species and use intensity data. Matrix data was then converted to percentages of each coral species relative to the total surface represented in the images. The matrices were statistically analyzed using ANOVA, the Shannon-Wiener diversity index, similarity and MDS analysis[18, 19, 20].

\section{RESULTS}

\section{Socioeconomic Valuation}

Demographic and socioeconomic results showed both formal education and income levels to be low in both towns (Table 1). In San Miguel de Cozumel, 38\% of interviewees had high school/vocational education (for youth 15 to 18 years of age in Mexico). In West End Village, most (52\%) of the interviewees had studied elementary school (for children 6 to 13 years of age in Honduras). At the time of the interview, $77.8 \%$ of the San Miguel de Cozumel sample and $90.5 \%$ of the West End Village sample earned from 0 to 3.9 daily minimum wages (for each country).

The primary personal reason for organizing and financially contributing to reef conservation was personal security in West End Village (54.5\%), and natural systems recovery in San Miguel de Cozumel (33.3\%). The second most important reason was natural systems recovery in West End Village (17\%) and recovery after a hurricane in San Miguel de Cozumel $(19.3 \%)$

In either town, only three interviewees understood the environmental consequences of coral reef loss. For almost all those interviewed $(98 \%)$, the main impact would be economic since the primary tourist attraction of the islands would be lost. Clearly, the interviewees did not understand the environmental services provided by reef systems, which is vital for those who live near and depend on them for sustenance.

Given the ecosystem options of beach, mangrove and reef, 55\% of those in West End Village stated that the ecosystem that most benefits them is the beach. If they were going to invest in ecosystem recovery it would be in either the beach $(39.8 \%)$ or the reef $(38.8 \%)$. In San Miguel de Cozumel, $70 \%$ stated the reefs provide the greatest benefit to them; $51 \%$ would invest in reef recovery and $32 \%$ in beach recovery.

When asked about their willingness to make monthly contributions (i.e. M-WTP) to finance coral reef conservation activities, the result was high: in San Miguel de Cozumel, $3.2 \%$ of true zero responses and $1.5 \%$ of protest zeros; and in West End Village, $1.05 \%$ of true zeros, $1.05 \%$ protest zeros and $1.05 \%$ did not know what they would contribute.

In West End Village, the M-WTP was $49.2 \%$ of the canasta basica alimentaria (CBA; roughly equivalent to income spent on basic food needs) in San Pedro Sula, Honduras (no CBA value is available for the Bay Islands). This is substantially higher than in San Miguel de Cozumel, where the M-WTP was equal to $10.6 \%$ of the Mexican national CBA. The M-WTP value in West End Village was equivalent to $9.6 \%$ of minimum wage at the time of sampling and in San Miguel de Cozumel it was $11.4 \%$ of minimum wage. Monthly income and WTP were correlated (Pearson, p<0.05) $(95 \%$ confidence) 
only in the West End Village sample: men ( $r=0.6100) ; 26$ - 30 years age group $(r=0.6210)$; and high school/vocational education level $(r=0.6500)$.

In both towns, the most important non-use values were the legacy value and the existence value. Based on the total monthly amount they would pay to support reef preservation activities on their island, the West End Village interviewees stated they would assign $37.0 \%$ to ensure their children's well-being, and $37.6 \%$ to ensure reef conservation because nature deserves to exist. In San Miguel de Cozumel, the interviewees would assign $38.3 \%$ to their children's well-being and $25.4 \%$ to reef preservation.

\section{Ecological evaluation}

In terms of coral species richness, thirty species from seventeen genera were identified at all three sampled sites (Table 3). The highest species richness value was observed at the Turtle Crossing (Roatan) non-intensive dive zone (NID). The lowest was recorded at the Chankana'ab (Cozumel) NID, although this was only one species lower than the adjacent intensive dive zone (ID). The genera Agaricia(Lamarck, 1801), OrbicellaDana, 1846, MontastraeaBlainville, 1830 and SiderastreaBlainville, 1830 were the only present at all four sample sites.

The values of live coral cover at each site and in each zone were calculated from the sampled area. Live coral coverage did not exceed $21 \%$ at any of the sites, but differences were observed between ID and NID zones (Table 4). Species percentage of total estimated live coverage was calculated for each site. In Chancana'ab, Orbicellaannularis(Ellis \&Solander, 1786) had the highest coverage, while in Turtle Crossingboth $O$. annularis and PoritesastreoidesLamarck, 1816 accounted for the highest proportion of coverage. Those species with the lowest coverage included Colpophyllianatans(Houttuyn, 1772), DichocoeniastokesiMilne Edwards \&Haime, 1848,Meandrinameandrites(Linnaeus, 1758), Montastraeacavernosa(Linnaeus, 1767) and Faviafragum(Esper, 1795).

Ecological diversity in terms of diversity and evenness index values varied little between sites at the same island (Figure 2). At Cozumel, the sampled sites exhibited little difference in diversity and their species had the same evenness level. Both sites at Turtle Crossing had the same species richness and therefore very similar diversity values. The 3D map, obtained from the similarity matrix (Bray-Curtis) in MDS, shows that Cozumel areas are markedly different. When seeking to determine similarity between $\mathrm{Bi}$ and $\mathrm{BNI}$ areas, the analysis turns to make a separation between the $\mathrm{BNI}$ and $\mathrm{BI}$ Cozumel sites in relation to the rest (Fig. 3a). The stress value $=0.01$ indicates that this is an excellent representation, so both maps used are reliable. This exploratory analysis doesn't show the existence of factor intensity differences due to diving (Fig.3b).

The results of the factorial ANOVA (intensity and dive site) to determine the existence of differences between areas, using community descriptors: richness $(S)$, diversity $\left(H^{\prime}\right)$ and equity $(J)$ show no statistically significant differences between the areas atboth sites due to the intensity of diving, but between them $(P=0.005447)$ (Fig.4)

\section{DISCUSSION}

\section{Socioeconomic}

A shared characteristic in the Roatan and Cozumel marine parks is the absence of community participation in their management and conservation. Data analysis showed this absence to be related to the population's low levels of information, education and training, as well as management plan implementation lacking a vision and mission that encompass collective construction of conservation activities. Nonetheless, a positive potential for community participation in coral reef conservation was observed in both towns.

Inhabitants of West End Village still lack satisfactory public services, and obtaining these services takes priority for them over ecosystem conservation. However, the contingent proposal made as part of the study was still accepted by $97.9 \%$ of participants. They could become genuinely interested in participating in marine park conservation efforts if they could develop solutions for a set of basic needs like safety and food. In San Miguel de Cozumel, services such as public safety and medical care are at acceptable levels. In conjunction with the belief that the reefs help promote tourism on the island, this helps to place natural ecosystem conservation in a privileged position among the population's priorities. The interviewees acknowledged the economic benefits they receive from the nearby natural systems (mainly coral reefs) and confirmed the presence of a supportive attitude that has led to collective action in the aftermath of climate disasters. Interest in maintaining the benefits they receive from tourism, the common denominator in both towns, led $95.3 \%$ of the overall sample to accept the contingent proposal used here.

Most study participants in both towns had minimal or no knowledge of the importance of coral reefs and the ecosystem services they provide. This was even the case in San Miguel de Cozumel where $38 \%$ of interviewees had studied at the junior and high school levels. Under these circumstances, the benefit they perceive as receiving from their respective reefs is limited to income from tourism activities; this is their fundamental knowledge of coral reefs.

Inhabitants of both towns identified the main value associated with their reefs as the well-being provided by their status as tourist attractions; in other words, the use value. This is to be expected since well over half the participants had jobs related to tourist services: $72.5 \%$ in West End Village and $81.3 \%$ in San Miguel de Cozumel.

The main intangible (non-use) value expressed by participants was the legacy value since family is a significant cultural element in both towns and the well-being of future generations is therefore important. The second intangible was the existence value, indicating that the interviewees believed the reefs to be significant because they are natural systems. 
This result is more in response to the environmental information available to town inhabitants than to their formal education level. The greater weight assigned the legacy value over the existence value may arise from the rural origins of many of the townspeople on both islands and their purchasing power. Many inhabitants are recent immigrants from the mainland, and their contact with the reefs is consequently recent. It is also difficult for them to access the reefs because they have little or no diving experience, largely the result of its very high cost.

Identification of the factors influencing participant WTP showed there to be a relationship between monthly income and the amount they were willing to contribute. The general correlation analysis using data from both towns indicated that WTP did not increase with monthly income. In contrast, analysis using only the West End Village data showed that M-WTP was positively correlated to monthly income. Conditions such as being of productive age, having studied or finished a high school or vocational program and being a man probably helped improve access to higher income. In San Miguel de Cozumel it was expected that relatively higher monthly income and education level would result in higher M-WTP (Table 2). San Miguel de Cozumel participants did express interest in the contingent proposal, but, perhaps due to their higher education level and greater income, they wanted more information to ensure that it was a trustworthy investment. Identifying what elements would effectively convince them to participate in a real financing proposal will require further research.

Low public confidence in the respective park administrations required the specification that contribution collection be under control of a citizens group. This is especially acute in San Miguel de Cozumel because Mexican citizens must constantly deal with the challenges of the legal framework of public institutions and their discretionary operation. In addition, local rural institutions (e.g. municipalities, ejidos, indigenous communities, social organizations, etc.) are in crisis due to a lack of training and a progressive breakdown of communities. Add these conditions to corruption within government organs, a lack of clear rules for resource distribution and access, challenges in implementing social development/natural resources conservation programs and difficulty in accessing institutional resources, and it is no surprise that Mexicans are highly skeptical of their government. The mere complexity of administrative processes in Mexico is another obstacle. To attain the theoretical goal of efficient and effective territorial administration and resources management would require the involvement of over ten environmental and non-environmental government organizations at the local, state and federal levels in all decision-making processes [21]. Indeed, successfully participating in a social program for personal ends can require an education level higher than that observed in the interviewees, experience in bureaucratic procedures and/or contracting of specialized counsel and management services.

In West End Village, the population is rural and depends largely on traditional reef fishing for subsistence. Here the townspeople require forums and spaces for activity reports, debate and presentation of their own proposals. Concrete problems could conceivably be resolved in areas such as reef conservation.

\section{Ecological}

The species richness results collected as part of the present study was compared to baseline data for the MRS gathered in 2002 [22]. In this study, a total of thirty-three coral species were reported with an average of 11 hard coral species (mean $=11 \pm 0.56)$. The maximum number of species $(23)$ was recorded at Xcalak Reefs and the minimum (7) at Manabique Point. In the present data, a total of thirty coral species were identified: thirteen at Cozumel and twenty-five at Roatan. Both richness figures are higher than the overall average species number for the MRS. The highest species richness was observed in the Turtle Crossing NID zone, but when compared to the ID zone (BI), the difference between them was only three species, which is not statistically significant. In particular way to Cozumel, Fenner[23] reported 63 species and 8 forms of scleractinian corals. In coastal areas of the Quintana Roo State, on average 12 to $21.6 \%$ coverage is reported [24,25]. Alvarez-Filip and Martinez-Nava [26] reported that seven species contribute more than $80 \%$ of the abundance, the most abundant Agariciaagaricites followed by Obicellaannularis. The website of the National Commission of Natural Protected Areas 2005-2008 [27] report for Cozumel Park a declining coverage 25 to $13 \%$ and a coverage ratio and the number of divers that might be significant; however it is a timely assessment and does not take into account other factors such as those caused by intrinsic changes in the environment.For Roatan, Fonseca [28] found that the percentage of coral cover was between 24.68 and $52.8 \%$; However a year later consequences of weather events, values are below the regional average for the SAM [29], although Keck [30] reported 52 species of scleractinian corals at depths of 2-8 m, with dominance Agariciaagaricites and Orbicellaannularis.

Previous reports on reef communities in countries forming part of the MRS contain species numbers and coral coverage percentages similar to those observed in the present study (Table 4) [31]. Nonetheless, ecosystem health in the studied zones is precarious. In 2002, a sufficient live coral coverage for the Caribbean reefs was estimated as 25-30\% [22]; none of the three highest coral percentages recorded here attain this level (Turtle Crossing NID $=20.3 \%$; ID $=12 \%$; Chankana'ab NID = 18.9\%). Clearly they have not recovered from myriad impacts past and present.

Coral coverage as a measure of reef health also shows how use intensity is affecting coral coverage, since live coverage percentages are lower in the ID zones than in the NID zones. This coincides with previous studies indicating that use intensity affects coral cover [22]. At Roatan, no statistics are kept of use intensity at the sampled reefs; probably only those in direct contact with the reefs could produce accurate estimates. As a result, park authorities are unlikely to have data useful in quantifying this problem. Both zones at Chankana'ab are within protected areas inside Cozumel Reefs Park. Snorkeling is the main activity in both because neither is very deep, which also facilitates contact between users and reef structures. The ID zone is used somewhat more by scuba divers, although dive service providers tend to take clients to sites with greater species abundance and richness. Artificial submarine structures, such as a giant Christ figure, are also 
popular, further diluting use pressure on the reefs. The low coral cover observed at this reef is largely due to severe meteorological events that have damaged the zone [26].

Reef structure height and diameter are useful indicators of reef structure integrity [25, 26]. In tourist use areas, these are telling indicators of user impact on reefs. Structure heights in the present study ranged from $5-7 \mathrm{~cm}$ and diameters averaged $30 \mathrm{~cm}$. Further analysis is needed that includes location, habitat, species growth habit and recruitment.

\section{CONCLUSIONS}

Both sampled marine parks exhibited signs of reef deterioration, although the data did not allow determination of impact origin, be it diving activity and/or other phenomena. Data were not collected on recruiting, growth, use intensity, and density of other reef organisms (e.g. macroalgae, etc.). These would aid in distinguishing anthropogenic from natural effects, and in evaluating how each type contributed or not to reef deterioration. However, general comparison with previous reports on reef condition found no marked differences (Table 5), suggesting that both reefs belong to the same system and share common problems.

Based on the socioeconomic results, their children and nature were the two main reasons the interviewed townspeople gave for possibly financing reef conservation actions. A comparison of M-WTP to indicators of basic needs satisfaction showed that the interviewees had a substantial interest in their reef zones. They were willing to contribute an average of $10 \%$ of the CBA and the minimum wage to finance conservation activities. They acknowledged that they depend on the reefs for their livelihood and were quite interested in participating in their conservation when the proposal was made to work with other townspeople. In both San Miguel de Cozumel and West End Village, positive conditions exist for citizen participation in coral reef conservation activities.

The challenges to park administrators under these circumstances are multifold. They need to develop and implement policy and practices that recognize and respect townspeople's rights; incorporate their knowledge, innovations and traditional practices; listen to and respect their views; ensure even distribution of faculties, responsibilities and benefits and promote fair incentives for all involved. Trust in park administrations and their management practices is vital when analyzing an inclusive management proposal. In a real (non-contingent) proposal, townspeople could finance conservation actions even when this would represent an expense in additional to their taxes. However, if park administrations do not demonstrate efficacy, congruence and transparency, community participation will not materialize.

Many factors affect if the interviewed townspeople's willingnesscould be transformed into action. According to Kennedy et al. [33], as long as an individual can express the value he assigns to the environment under certain circumstances, other priorities such as personal and financial safety can influence her/his behavior to the benefit of the environment. In San Miguel de Cozumel and West End Village, the factors that would affect a decision to participate in a real proposal for financing and organizing reef conservation actions would include sensitization and education in direct contact with the reefs, as well as providing timely and relevant biological and environmental data. If the Cozumel and Roatan NPA management programs are not applied in a coordinated manner with scholastic and non-scholastic educational programs, civic strategies, scientific research and legal institutions, they will not be perceived as beneficial by society and will not provide benefits to the ecosystem. Past experiences in NPAs confirm that detachment, lack of negotiation and inequality among social forces entail high costs.

\section{ACKNOWLEDGMENTS}

CONACYT-México and Russel Train Foundation (Funding) for support of this research. Jorge Araña, UPGC, España (Collaboration in the preparation of the questionnaire). Alicia Medina, WWF (binational mediation). Alicia PootSalazar ,Parks and Cozumel Museums Foundation:Jesús Benavides y Chankana'ab Park (sampling collaboration). Grazzia Matamoros y Nick Bach, Parque Marino West Bay, West End y Sandy Bay (logistic sampling in Roatán).

\section{REFERENCES}

[1] IUCN. 2012. Annual Report: Nature+ toward nature- based solutions, IUCN, Switzerland.

[2] Wilkinson, C. (Ed). 2008. Status of Coral Reefs of the World: 2008. Global Coral Reef Monitoring Network y Reef and Rainforest Research Centre. Townsville, Australia.

[3] Burke, I., Maidens, J.,Spalding,M.,Kramer, P., Green, E.,Greenhalgh, S., Nobles, H. y Kool, J.2004. Arrecifes en peligro en el Caribe. WorldResourcesInstitute. Washington D.C. USA. 80 pp.

[4] Aiello, D.P. 2007. Coast to coral: evaluating terrestrial development's relationships to coral ecosystem condition in Roatan, Honduras. Master of Arts Thesis.College of Arts and Sciences of Ohio University.USA.

[5] Sánchez C. A. and Propín, F. E. 2003. Dependencias regionales del turismo en la Isla de Cozumel, México.Cuadernos de Turismo.11:169-180.

[6] Phillips A. (Editor series). 1998. Task Force on Economic Benefits of Protected Areas of the World Commission on Protected Areas (WCPA) of IUCN, in collaboration with the Economics Service Unit of IUCN. Economic Values of Protected Areas: Guidelines for Protected Area Managers, IUCN, Gland, Switzerland and Cambridge, UK. 


\section{ISSN 2321-1091}

[7] Panadero, M., Navarrete G. y Jover, F. 2002. Turismo en espacios naturales: oportunidades en el Corredor Biológico Mesoamericano, Cuadernos de Turismo, no. 10, Universidad de Murcia. Murcia, España. pp. 69-83.

[8] Santander, L. C. y Propin, E. 2009. Impacto ambiental del turismo de buceo en arrecifes de coral, Cuadernos de Turismo, no. 24, Universidad de Murcia. Murcia, España. pp. 207-227.

[9] Chávez-Hidalgo, A. 2009. Conectividad de los arrecifes coralinos del Golfo de México y Caribe Mexicano. M.S. Thesis. Centro Interdiciplinario de Ciencias Marinas. IPN. México, pp 167. 2009

[10] WWF. 2012.Mesoamerican Reef Report, WWF global.

[11] Arnaiz, B. S. M. 1996.Turismo en el Caribe Continental. Estudios y perspectivas en Turismo. 5:147-163.

[12] A. Sánchez-Crispín, A. y Luna, J. 2000. Visión geográfico-económica del turismo en la isla de Cozumel a fines del siglo XX. Proceedings dellV Congreso Internacional de Mayistas, Guatemala.

[13] Gobierno de Quintana Roo (ed). 2010. IV informe de Gobierno de Quintana Roo, Capítulo III.3 Diversificación del turismo.Consulted: 25 de octubre de 2014. http://cuartoinforme.qroo.gob.mx/Documento/33.php.

[14] Harborne, A. R., AfzalD. C. and Andrews, M. J. 2001.Honduras: Caribean Coast. Marine Pollution Bulletin. Vol 42, no. 12 pp. 221-1235.

[15] Administración Forestal del Estado. 2007. Plan de manejo del Parque Nacional West Bay, West End y Sandy Bay, Corporación Hondureña de Desarrollo Forestal y Departamento de Áreas Protegidas y Vida Silvestre, Honduras, CA. 146 pp.

[16] I. J. Bateman, I, J., Carson, R. T., Day, B., Hahnemann, M., Hanley, N.,Hett, T., Jones-Lee, M.,Loomes, G., Mourato, S., Özdemiroglu, E., Pearce, D. W., Sugden, R. and Swanson, J. 2002.Economic valuation with stated preference techniques, a manual.Edward Elgar Publisher.UK.

[17] Torruco, D. 1995. Faunística y Ecología de los Arrecifes Coralinos del Sureste de México, Ph.D. thesis, Universitat de Barcelona, España.

[18] Pielou, E.C. 1984. The interpretation of ecological data: A primer on classification and ordination, Wiley-Interscience Publ. New York.

[19] Magurran, A.E. 1988.Ecological diversity and its measurement. Princeton University Press, USA, 1988

[20] Honarkhah, M. and Caers, J. 2010. Stochastic simulation of patterns using distance-based patterns modeling. Mathematical Geoscience 42:487-517.

[21] Arellano, C., Bulir, A., Lane, T. and Lipschitz, L. 2009.Dynamic implications of foreign aid and its variability, Journal of Development Economics, no. 88, pp 87-102.

[22] Almada-Villela, P.,McField, M., Kramer, P., Richards, K.and Arias-González, E.2002. Status of Coral Reefs of Mesoamerica- Mexico, Belize, Guatemala, Honduras, Nicaragua and El Salvador, in: Status of Coral Reefs of the world,C. Wilkinson Ed., pp. 303-324, Global Coral reef monitoring network. Australian Institute of Marine Science.

[23] Fenner, D.P. 1999. New observations on the stony coral (scleractinia, milleporidae and stylasteridae) species of Belize (Central America) and Cozumel (Mexico).Bulletin of Marine Science. 64(1):143-154.

[24] Ruiz, Z. M.A. 2000. "Análisis espacial del reclutamiento coralino y condición arrecifal en el Caribe mexicano". Tesis de Maestria. CINVESTAV-IPN. México. 102 pp.

[25] Hernández, L.R.C. 2004. "Variación espacial de la cobertura de corales escleractínios y descripción de condición arrecifal a lo largo del Caribe Mexicano y un arrecife del Banco de Campeche". Tesis de Maestría. CINVESTVIPN. México. $102 \mathrm{pp}$.

[26] Alvarez-Filip, L. and Nava-Martinez, G. 2006. Reporte del efecto de los huracanes Emily y Wilma sobre arrecifes de la costa Oeste del Parque Nacional Arrecifes de Cozumel. Parque Nacional Arrecifes de Cozumel y Comisión Nacional de Áreas Naturales Protegidas. México.

[27] Comisión Nacional de Áreas Naturales Protegidas. 2010. "Dirección del Parque Marino Arrecifes de Cozumel". http://www.conanp.gob.mx/anp_pruebas/cozumel/ingles/monitoreo.php Fecha de consulta: 23 Agosto 2010.

[28] Fonseca, A. 1997. "RappidAssesment of the Sandy Bay/West End marine Reserve (RMSW) Reef system". Limits and zonification.Management Priorities and Recommended Reef Monitoring Plan. 8pp.

[29] McField, M. and Kramer, P. R. 2007. "Healthy Reefs for Healthy People: A Guide to Indicators of Reef Health and Social Well-being in the Mesoamerican Reef Region. WithcontributionsfromGorrez, M. and McPherson, M. $208 \mathrm{p}$

[30] Keck, J. 2000. "The Roatan Institute for Marine Sciences: Instructors Guide". Roatan Institute for Marine Sciences.Sandy Bay, Roatán. Honduras. 70 pp.

[31] Hawkins, J. P., Roberts, C.M., Hof, T. V., De Meyer, K., Tratalos, J. and Eldam, C. 1999.Effects of recreational scuba diving on Caribbean coral and fish communities.Conservation Biology, vol. 13, no. 4, pp. 888-897. 


\section{ISSN 2321-1091}

[32] Burke, L.and Maidens, J. 2005.Arrecifes en peligro del Caribe,WorldResourceslnstitute. 80 pp.

[33] Kennedy, E. H., Beckley, T. M., McFarlane, B. L. and Nadeau, S. 2009. Why we don't "walk the Talk: Understanding the environmental values/behavior gap in Canada". Human Ecology Review. 16:151-160.

TABLES

Table 1. Socioeconomicsamplingcharacteristic

\begin{tabular}{|l|c|c|}
\hline & San Miguel de Cozumel & West EndVillage \\
\hline Women & $55 \%$ & $47 \%$ \\
\hline Men & $45 \%$ & $33 \%$ \\
\hline Average age of the sample & 30 años & $29 \%$ \\
\hline Married & $49 \%$ & $41 \%$ \\
\hline Single. & $43 \%$ & $52 \%$ \\
\hline Some degree of basic education at most. & $48 \%$ & - \\
\hline Some upper secondary education level at most & $42 \%$ & $0 \%$ \\
\hline Services and trade as the main economic activity. & $18 \%$ & 31.7 USD \\
\hline Not paid (student or housewives) & 0 USD & 3999 USD \\
\hline Lowestmonthlysalary. & 6397 USD & 35.3 USD \\
\hline Highestmonthlysalary & 121.5 USD & 181.4 USD \\
\hline Income spent on basic food needs & 113.5 USD & \\
\hline Minimumwage & & \\
\hline
\end{tabular}

Table2 Monthly willingness-to-pay in both National Park.

\begin{tabular}{|c|c|c|}
\hline San Miguel de Cozumel & & West EndVillage \\
\hline $12.9 \pm 11.84$ & WTP $^{*}$ & $17.4 \pm 15.78$ \\
\hline 10 & Median & 10 \\
\hline 10 & Mode & 5 \\
\hline
\end{tabular}

*average \pm standarddeviation

TABLE 3. Corals identified in the countries studied. The richness in each site according to diving intensity is show.

\begin{tabular}{|l|c|c|c|c|}
\hline \multicolumn{1}{|c|}{ Specie } & $\begin{array}{c}\text { Chankana'ab } \\
\text { Cozumel ID }\end{array}$ & $\begin{array}{c}\text { Chankana'ab } \\
\text { Cozumel NID }\end{array}$ & $\begin{array}{c}\text { Turtle } \\
\text { CrossingDI }\end{array}$ & $\begin{array}{c}\text { Turtle } \\
\text { Crossing NID }\end{array}$ \\
\hline Acroporacervicornis & & & & + \\
\hline A. palmata & & & + & + \\
\hline Agariciaagaricites & & + & + & + \\
\hline A. tenuifolia & & + & + & + \\
\hline A. fragilis & + & & + & + \\
\hline Colpophyllianatans & & & + & + \\
\hline Dendrogyracylindrus & & & + & + \\
\hline Dichocoeniastockesii & & + & & + \\
\hline Diploria clivosa & & & + & + \\
\hline
\end{tabular}




\begin{tabular}{|c|c|c|c|c|}
\hline D. laberynthiformis & & & + & + \\
\hline Eusmiliafastigiata & + & + & + & \\
\hline Faviafragum & & & + & + \\
\hline Isophyllia sinuosa & + & & & \\
\hline Leptoseriscucullata & & & + & + \\
\hline Maniciniaareolata & + & & & \\
\hline Montastraea cavernosa & + & + & + & + \\
\hline Mycetophylliaaliciae & & & + & + \\
\hline M. lamarckiana & & & + & + \\
\hline Orbicellaannularis & + & + & + & + \\
\hline Poritesastreoides & & & + & + \\
\hline P. furcata & & & + & + \\
\hline P. porites & & 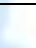 & 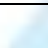 & + \\
\hline Pseudiploria. strigosa & + & & + & + \\
\hline Siderastrearadians & & + & + & + \\
\hline S. siderea & + & + & + & + \\
\hline Solenastraeabournoni & & & + & + \\
\hline S. hyades & & & & + \\
\hline Stephanocoeniamichellini & + & & & \\
\hline Riqueza total & 9 & 8 & 19 & 22 \\
\hline
\end{tabular}

TABLE 4.Live coverage percentages on reefs studied. It shows the total live coverage and sampling area on each reef.

\begin{tabular}{|l|c|c|}
\hline \multicolumn{1}{|c|}{ SPECIES } & \multicolumn{2}{c|}{ COZUMEL } \\
\hline \multicolumn{1}{|c|}{ MEXICO } & Chancanaab & Chancanaab \\
(ID) & (NID) \\
\hline Agariciaagaricites & 0.12 & - \\
\hline Agariciafragilis & - & 5.7 \\
\hline Agariciatenuifolia & 0.1 & - \\
\hline Dichocoeniastockesii & 1.08 & - \\
\hline Eusmiliafastigiata & 0.12 & 5.6 \\
\hline Isophyllia sinuosa & - & 6.1 \\
\hline Manicinaaerolata & - & 25.5 \\
\hline Montastraea cavernosa & 11.56 & 29.6 \\
\hline Orbicellaannularis & 76.64 & 14.5 \\
\hline Pseudodiploriastrigosa & - & - \\
\hline Siderastrea radians & 0.06 & 3.0 \\
\hline Siderastrea sidereal & 10.32 & 5.2 \\
\hline Stephanocoeniamichelinii & - & 1.14 \\
\hline & $171729 \mathrm{~cm}^{2}$ & $800 \mathrm{~cm}^{2}$ \\
\hline Total & & ROATAN \\
\hline
\end{tabular}




\begin{tabular}{|c|c|c|}
\hline HONDURAS & $\begin{array}{l}\text { Turtle crossing } \\
\text { (NID) }\end{array}$ & Turtle crossing (ID) \\
\hline Acroporacervicornis & 0.48 & - \\
\hline Agariciaagaricites & 10.20 & 10.9 \\
\hline Agariciafragilis & - & 11.1 \\
\hline Colpophyllianatans & 0.79 & 0.1 \\
\hline Dendrogyracylindrus & 1.32 & - \\
\hline Dichocoeniastockesii & 0.03 & 0.7 \\
\hline Diplorialabyrinthiformis & 2.82 & 12.4 \\
\hline D. clivosa & 0.10 & - \\
\hline Eusmiliafastigiata & - & 0.2 \\
\hline Faviafragum & 0.03 & 0.1 \\
\hline Leptoseriscucullata & 0.03 & 0.2 \\
\hline Montastraea cavernosa & 0.76 & 2.5 \\
\hline Mycetophylliaaliciae & 0.31 & 0.2 \\
\hline Mycetophyllialamarckiana & 0.10 & 0.3 \\
\hline Orbicellaannularis & 46.69 & 27.0 \\
\hline Poritesastreoides & 19.89 & 21.5 \\
\hline Poritesfurcata & 3.11 & 0.3 \\
\hline Poritesporites & 0.10 & 0.9 \\
\hline Pseudodiploriastrigosa & - & 2.4 \\
\hline Siderastrea radians & 0.29 & 0.7 \\
\hline Siderastreasiderea & 9.24 & 6.8 \\
\hline Solenastreabournoni & 2.15 & 1.7 \\
\hline Solenastreahyades & 1.63 & - \\
\hline $\begin{array}{ll} & \text { Total }\end{array}$ & 20.3 & 12.0 \\
\hline Sampledarea & $332024 \mathrm{~cm}^{2}$ & $332024 \mathrm{~cm}^{2}$ \\
\hline
\end{tabular}

TABLE 5.Species number and coral cover percentage in the MRS subregions and the reefs studied.

\begin{tabular}{|l|c|c|}
\hline \multicolumn{1}{|c|}{ MRS Subregion } & Coralsspecies & \% Coralscovers \\
\hline Norte de Quintana Roo* & 24.5 & 10.1 \\
\hline Norte de Honduras* & 27.6 & 18.9 \\
\hline Cozumel+ & 13 & 20.3 \\
\hline Roatán+ & 25 & 24.5 \\
\hline
\end{tabular}

*Almada-Villeda et al. 2002

+Thiswork 


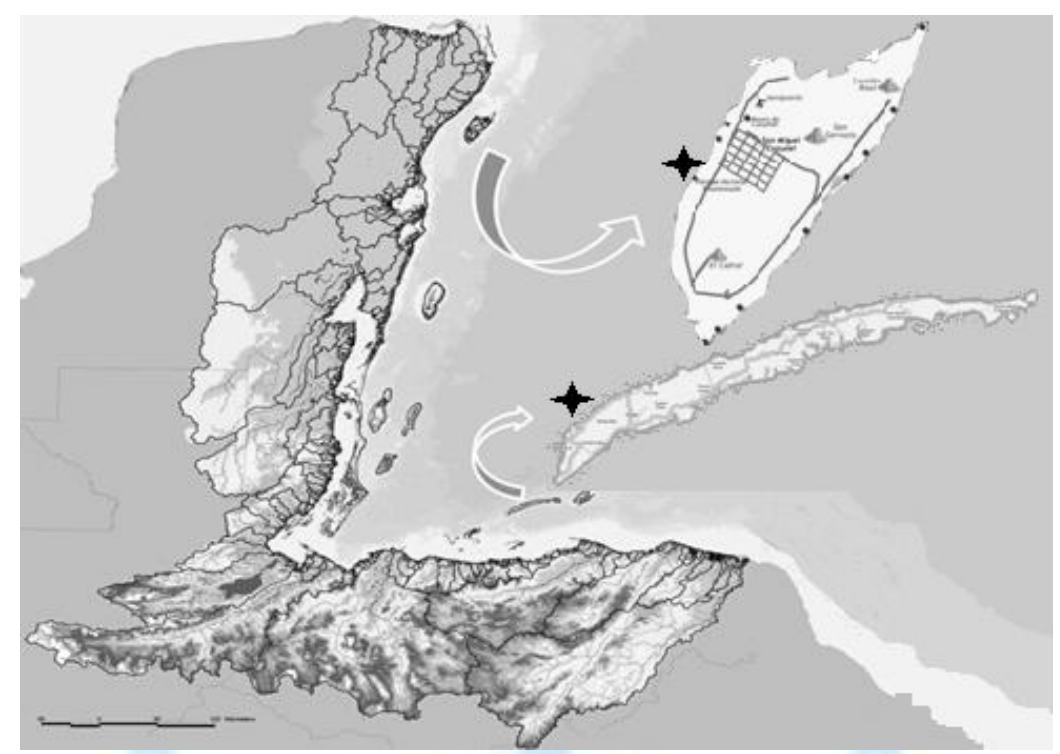

Figure 1. Samplingsites.

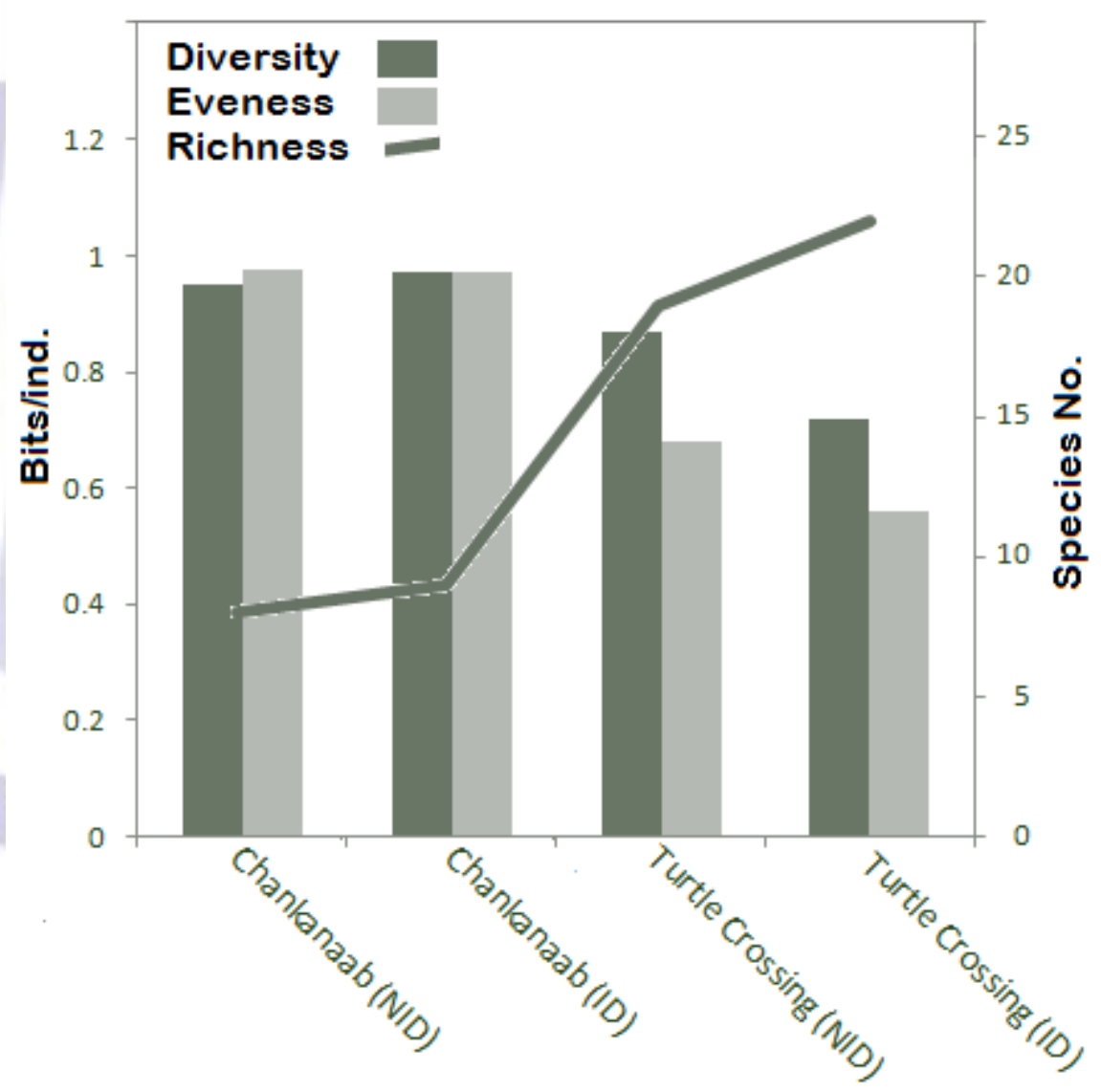

Figure 2. Diversity values $\left(\mathrm{H}^{\prime}\right)$, Equity $(\mathrm{J}$ ') and species richness on reefs analyzed for both SAM parks. It shows that the highest diversity value recorded corresponds to Chancanaab (BI and BNI) in Cozumel, Mexico and the lowest in Turtle Crossing (BNI) in Roatan, Honduras; However, the highest values of species richness was presented Turtle Crossing in Roatan and the lowest in Chancana'ab, Cozumel, higher values occurred in Chancana'ab equity, and the lowest in Turtle Crossing. 


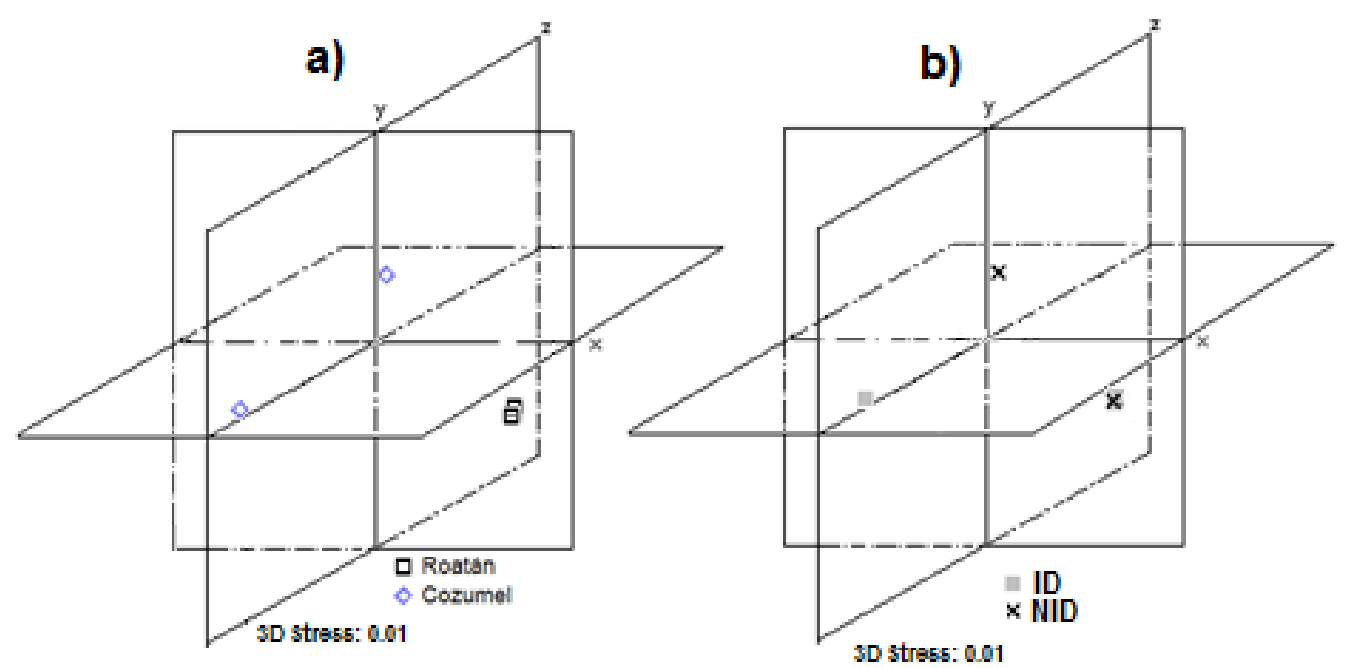

Figure 3. Map of site-similarity and different intensity zones diving.

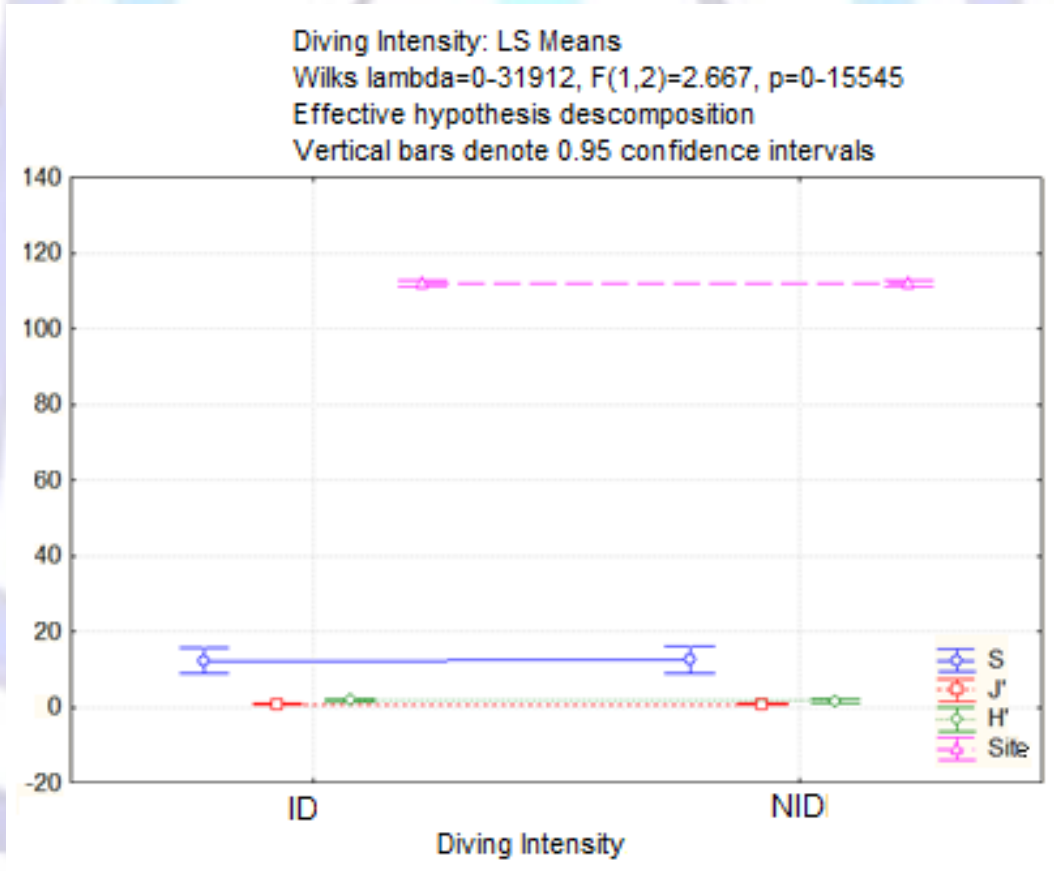

Figure 4.ANOVA comparing the effect of the intensity of diving in terms of biodiversity sites. 